\title{
RESIDENTIAL ENVIRONMENT AND TERRITORIALLY FUNCTIONAL STRUCTURE OF THE BRNO CITY IN THE PERIOD OF TRANSFORMATION
}

\begin{abstract}
O. Mikulík, A. Vais har: Residential Environment and Territorially Functional Structure of the Brno City in the Period of Transformation. - Geografie-Sborník ČGS, 101, 2, pp. 128 - 142 (1996). - The article evaluates the residential environment of Brno according to the individual town wards. A more detailed analysis is done for the centre of the town. Parametres of housing resources, environment hostile functional clashes, extent of green areas and state of social environment have been taken into consideration. The results show a bad residential environment in the industrialized town wards in flat relief and a good one in the town wards situated in articulated relief.

KEY WORDS: residential environment, functional structure, Brno
\end{abstract}

\section{Residential environment and territorially functional structure}

One of aspects of conceiving environment in a city is the conception of residential environment. This conception considers towns and settlement systems as environment for life, especially for human housing. Residential environment is defined as that part of human environment in which mainly the complex function of housing is materialized. Housing is a process of cyclically repeating and changing activities of inhabitants aimed at reproduction and development of their life. The function of housing includes not only a simple accommodation, but also activities connected with family life and housekeeping, family economics, newly with business (when run directly in the domicile), leisure, self-realization, etc. It is composed of natural, technical and social environment. The residential environment can be understood as interior (flat and house) and exterior (Horký, I., 1984).

Its differentiation on the urban territories has its laws given by the interaction of historical and present-day aspects of physical-geographical position, social-economic function and social differentiation. The evaluation consists in identification and quantification of positive and negative aspects of housing and quality of life in different types of residential districts. The research methods used are mainly the field research and mapping, using of statistical data and position analysis. Individual characteristics of flats or of their inhabitants are not objects of research.

The problem's structure is the following:

a) characteristics of flat resources

- evaluation of technical equipment of flats (category or different equipment),

- evaluation of using of flat resources,

- evaluation of household's equipment by objects of long-term consumption 
b) characteristics of house resources

- houses according to their ownership (family houses, private, communal and co-operative flat houses),

- height level of houses

- material of supporting walls

- character of housing (streets, loose, blocks of flats)

c) characteristics of natural environment and its state

- relief inclination

- mesoclimatic conditions and their impact on health

- green areas, their extent, proximity and quality

- pollution of natural environment directly influencing the quality of residential environment

d) characteristics of residential district

- technical infrastructure for housing

- local social infrastructure

e) social characteristics

- structure of population

- stability of population

- presence of risk groups of population and security factor

- acceptability for establishing social contacts

f) characteristics of location

- with respect to work possibilities

- with respect to extra-local services

- with respect to recreation areas

- with respect to transport facilities

The above-mentioned 21 factors do not form an absolutely exhausting list. They are mainly factors which can be quantified or at least qualitatively defined and evaluated. The evaluation is done from the viewpoint of the residential function, that means from the viewpoint of the inhabitant of the given residential district. In the same time, there is an interference of general factors (typical for different types of residential districts) which become objects of generalization with the individual ones.

The most general possibility is to compare the residential environment of different towns or of their parts. Accessible statistical data or elaborated typologies can be frequently used. This approach can offer certain global characteristics which would rather illustrate the position of different residences in the system of settlement and in localizing the system of national economics, the degree of urbanization and the physical - geographical region. Nevertheless especially in the case of towns, it gives too averaged values which, because of an increasing social differentiation, do not illustrate the real state of residential environment. A certain possibility to approach the reality might be using this approach for generalization of a more detailed research work. The representation of different types of residential districts, the characteristics of which will be generalized, will help to evaluate the real structure of the residential environment quality even in the inter-urban comparison, without nevertheless taking into account individual factors. 
Such generalization must be preceded by an analysis of residential environment within towns and settlement systems. According to present-day findings, following principal types of residential districts (which can be further divided into subtypes) can be classified:

- urban brick flat houses of the pre-industrial, industrial and betweenwars period,

- flat houses of early socialist period built in streets,

- estates of prefabricated blocks of flats,

- working class and Romany lodgings,

- residential districts of villa-type of the pre-war period,

- after-war family houses built in streets, detached or semi-detached,

- suburbs at principal roads.

The empirical research can attribute certain typical characteristics to each of the above-mentioned types or sub-types. Different types (which can be permeable mutually and with other functions) form on the territory of towns a structure which can be in a certain way generalized. This structure in combination with individual characteristics of residential environment gives a definitive view on differentiation of residential environment quality in towns. This structure can be cartographically mapped and analysed from the point of view of residential and functional structure of towns and definition of reconstruction zones. The quality of residential environment is likely to be soon exprimed by flats and lots prices. In this sense, it is related also to the socalled housing problem.

The methods of our analysis of the residential environment quality consist in putting together the evaluation of statistical data on different residential districts on the basis of data on houses and flats resources from the census of inhabitants, houses and flats on March 2, 1991, and possibly also other statistical data and field mapping and analyses of different residential districts, streets and houses. Experience of analyses of the social environment level in different types of housing (Vaishar, A., 1988) have been used. Also the method of analysing territorial and functional structure and territorial clashes has been used for identification of residential districts problems. Statistical data, if disposable, are used for possible specification and quantification of problems. The method has been verified during a several-year basic research Vaishar $(1989,1990,1995)$ and in application studies in number of Moravian towns. Evaluation of territorial and functional structure has been done from the viewpoint of penetration, or neighbourhood, of functional zones with a more pronounced negative impact on the residential environment (production and transport zones) and with stressed claims on the quality of environment (recreation zones, residential and near-centre facilities).

An attentive reader will certainly notice that all the criteria of residential environment evaluation, given in the theoretical part, are not discussed in this paper. Some of them are not relevant at the level of town wards part or urban districts, others are hidden in the complex of other evaluated items. When analysing the residential environment, the attention was aimed mainly at the following aspects: technical equipment and using of housing resources, type and age of housing resources (compare Očovský, Š., 1989), localization of residential district with regard to sources of pollution and to environment deterioration, aesthetic qualities of environment, quantity and quality of green areas, equipment, social environment (compare Hapl, L., Link, J., 1985). 
The first stage of evaluation of the internal differentiation of the residential environment has been done according to different town wards. The further stage has been devoted to a detailed analysis of the town ward Brno - Centre according to different urban districts. Only urban districts with residential function have been taken into consideration. From pragmatic reasons, individual urban districts have been identified with residential districts, although in fact they can be composed of several districts or represent a mixture of different types of buildings. Following aspects have been evaluated: parametres of housing (technical equipment, density of population), functional clashes, state of social environment, possibility of compensation of stresses in green areas. Different aspects have been evaluated by a point scale within the interval 1 to 5 . The verbal description of point values is the following:

Housing:

1 - the best technical equipment of housing resources, the highest habitable surface per person, the lowest number of persons per room

2 - a good technical equipment, a high habitable surface per person, a low number of persons per room or inconsistent characteristics among which positive aspects are nevertheless prevailing

3 - average characteristics of housing or inconsistent ones with a globally neutral aspect

4 - a bad technical equipment, a low habitable surface per person, a high number of persons per room or inconsistent characteristics with a prevailingly negative aspect

5 - the worst technical equipment, the lowest habitable surface per person, the highest number of persons per room

Functional clashes:

1 - neither in the urban district, nor in its neighbourhood, there are no activities disturbing residential function

2 - there is a less important functional clash with transports or medium clash with activities in neighbouring urban districts

3 - there is a more important clash with transports or industry or several less important functional clashes or an important clash with activities in neighbouring districts

4 - there are very important clashes, or possibly medium important clashes in a greater quantity and in the majority of the territory

5 - the urban district is a place of complex functional clashes, possibly even stressed by clashes in the neighbourhood

The state of social environment:

1 - a stable environment of districts with family houses with normal age structure of population and without disturbing effects

2 - a relatively stable environment of older mixed housing with minimum of disturbing effects

3 - social environment of near-centre territories with relatively stabilized population, but with a great number of newly arrived which diminishes the level of social control, social environment in neighbourhood of large parks with a reduced level of security

4 - social environment of districts of newer flat houses, mainly in open areas, characterized by a low level of social control and with a high instability of population

5 - social environment of deprived town quarters with a higher frequency of socially feeble and unstable strata of population

Compensation of stress factors through green areas:

1 - the urban district is rich in green areas, mainly in combination of family houses gardens, of gardens near social facilities, of trees in streets and of smaller parks

2 - the urban district has a sufficient quantity of green areas which are possibly completed by green areas in the neighbourhood

3 - in the structure of the urban district, green areas, possibly completed by green areas in the neighbourhood, are represented

4 - the urban district has less important green areas or there are more important green areas in the neighbourhood 
5 - the urban district nearly lacks green areas and even in the neighbourhood, there are no larger or qualitatively satisfactory green areas

We are aware that the individual evaluated aspects are not complete and not equally important. We nevertheless suppose that any equal importance cannot be objectively settled, as its character is subjective. The most deficient lacking factor is generally considered as the most important one. For that reason, when interpreting the results it is necessary to take into consideration always not only the total sum of points, but also their structure. In urban wards, it is necessary to take into consideration that their residential environment can be largely differentiated and the average level must not express the state of each of its parts. As the same criteria have been used for of evaluation of town wards and urban districts of Brno - City, extreme values for town wards do not appear in certain criteria.

\section{Brno town in the period of transformation}

The evaluation of the residential environment level and of the territorially functional structure must be also based on the evaluation of functions of the town in the period of transformation. Brno is the second most important town in the Czech Republic and the most important centre of Moravia. It has 390,000 permanent inhabitants (1994), about 80,000 persons are regularly coming to study, to work, to use the services or other facilities in the town. The position of the town in the national system of settlement (for more details, see Vaishar, A., Mikulík, O., Zapletalová, J., 1995) corresponds to its advantageous localization, to its historical development, early connection to the railway net and to the localization of some supraregional functions.

Among the basic urban functions of Brno, we will mention mainly the following ones:

- commerce and tradefairs

- science, schools, culture, innovation

- industries

- transports and storage

- central servicing

- tourism

- administration

Realization of the above-mentioned functions must be reflected in the internal structure of the town and in its environment. Situation in three model problems sets has been analysed: transports, green areas and of retail trade distribution (Vaishar, A., Mikullík, O., Zapletalová, J., Barták, R., Dokoupil, M., 1995). A comparison with towns of similar size in Italy and Great Britain has shown that the present decisive feature of the decision making process in the sphere of the structure of the town and its environment in the conditions of the Czech Republic is namely the transformation, that means also to search optimal forms of town administration and their low stability.

According to Zahradníček (1993), there are two basic conceptions: one of them is based on the opinion that Brno has already reached its maximum and that a further development is not desirable, the other one is convinced that the prosperity potential of the town is not yet exhausted and that, on the contrary, new sources have appeared. According to our opinion, the problem 
of the development essence is important. A further quantitative increase of population is really undesirable and, in addition, it is opposed to the present development trends of towns in the corresponding stage of urbanization. On the other side we are convinced that a qualitative development, understood as development of the prosperity of the town, is not only desirable, but that new sources can be found. This qualitative development must nevertheless take into consideration not only the town in its administrative limits, but the whole urban region which will be progressively penetrated by suburban activities.

The traced perspectives will certainly reflect into the progressive reconstruction of the internal structure of the town and of its individual wards. Mainly the following changes can be considered: Clearance of the large and heavily devastated industrial areas near the railway station will improve the environmental situation of that zone. On the contrary, a deterioration of environment can be expected as a consequence of a rapid increase of individual transports. This increase will be due to realization of all the above-mentioned functions. For that reason, the solution of transports problems is the major task of the town development. Following partial problems are concerned: interconnection of internal and external transports, transfer of the railway station, conception of the airport, parking facilities in all parts of the town, public transport organization, solution of transit roads, etc.

Equally the problem of residential environment is important in the sketched connections. The residential environment is probably the most important aspect of the environment from the human viewpoint. The culture of the residential environment should largely correspond to the cultural importance of the town. Another topical problem is the competition for human resources between towns and regions. At present, an absolute growth of population is not important, but it is necessary to gain elites of different branches of human activities. A good residential environment can be one of the most attractive offers of Brno for these persons.

The small and middle business has some other claims on the residential environment. It is important to harmonize the residential and the work functions of different districts. The transformation changes also other aspects of the residential environment, the differentiation of the residential environment is increasing. The question naturally is, in which extent, in which time and in which proportion Brno will be affected by suburbanization processes, that is by a transfer at first of commercial and work activities and consequently also of housing from the inner city and by the gentrification, that is revitalization of the residential environment in the inner city (Sýkora, L., 1993).

\section{Evaluation of the Brno residential environment}

On the basis of the above-mentioned methods, the evaluation of residential environment has been done in different town parts. The results are shown in Figure 1 and in Table 1.

The worst evaluated town wards have been Brno-Centre and Brno-South, where the functional clashes are the most intensive. Already this statement shows the necessity of a corrected correlation of obtained results. Although the central part of Brno and the industrial ward Brno-South have approximately the same characteristics of a not very good housing, of scarce green 


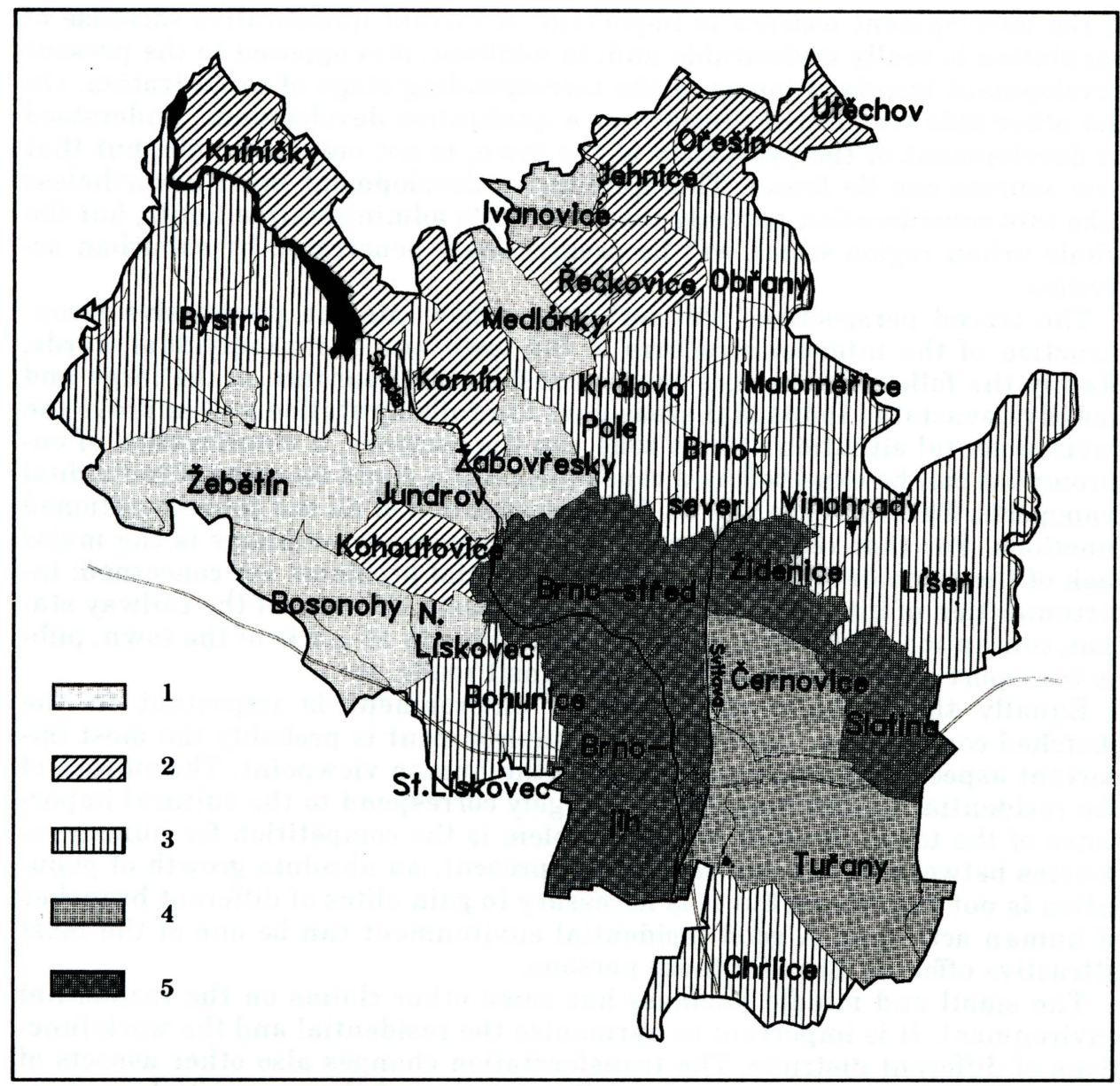

Fig. 1 - Brno: Quality of dwelling environment: 1 - very good (7-8 points - see Table 1), 2 good (9-10), 3 - medial (11-12), 4 - poor (13-14), 5 - very poor (15-16)

areas, of migration of socially deprived population and of clashes of varied functions, including an intensive transport of all kinds and of industry (industrial works are even older in Brno-Centre), the attractiveness of both quarters is diametrically different. While Brno-Centre is highly attractive, Brno-South really represents one of the worst addresses in the town. The cause can be hardly quantified, but in the case of a town centre there is a genius loci which will make of the centre the principal point of the town even in the process of the expected suburbanization.

Another group of town wards with functional problems is located in the south-eastern sector. Average levels are given to unilaterally developed estates of blocks of flats and also to number of larger town wards with diversely developed functions. In the last case, the average evaluation is rather a result of making an average of quite different values than a homogenous quality.

Ancient country settlements at the town margins have been mostly evaluated as level 2. Their main functional problem is their distance from the cen- 
Table 1 - Evaluation of residential environment in Brno town wards

\begin{tabular}{|r|l|r|r|r|r|r||l|l|r|r|r|r|r|}
\hline & part & A & B & C & D & total & & part & A & B & C & D & total \\
\hline 1 & Bohunice & 3 & 3 & 3 & 3 & 12 & 16 & Líśeń & 4 & 3 & 3 & 1 & 11 \\
2 & Bosonohy & 3 & 2 & 2 & 1 & 8 & 17 & Medlánky & 3 & 2 & 2 & 1 & 8 \\
3 & Brno-sever & 3 & 3 & 3 & 2 & 11 & 18 & Nový Lískovec & 3 & 2 & 2 & 1 & 8 \\
4 & Brno-střed & 3 & 5 & 4 & 3 & 15 & 19 & Obřany-Maloměřice & 4 & 3 & 3 & 2 & 12 \\
5 & Bystrc & 3 & 3 & 4 & 1 & 11 & 20 & Ořešín & 4 & 2 & 3 & 1 & 10 \\
6 & Cernovice & 4 & 3 & 3 & 4 & 14 & 21 & Rečkovice & 3 & 2 & 3 & 1 & 9 \\
7 & Chrlice & 3 & 3 & 3 & 3 & 12 & 22 & Slatina & 4 & 4 & 3 & 4 & 15 \\
8 & Ivanovice & 3 & 2 & 2 & 1 & 8 & 23 & Starý Lískovec & 3 & 3 & 3 & 3 & 12 \\
9 & Jehnice & 4 & 2 & 3 & 1 & 10 & 24 & Tuřany & 4 & 3 & 3 & 3 & 13 \\
10 & Jundrov & 3 & 1 & 2 & 1 & 7 & 25 & Útěchov & 4 & 2 & 2 & 1 & 9 \\
11 & Kníničky & 3 & 2 & 3 & 1 & 9 & 26 & Vihohrady & 3 & 3 & 4 & 2 & 12 \\
12 & Kohoutovice & 3 & 2 & 4 & 1 & 10 & 27 & Žabovřesky & 2 & 2 & 2 & 2 & 8 \\
13 & Brno-jih & 4 & 5 & 3 & 4 & 16 & 28 & Žebětín & 3 & 2 & 2 & 1 & 8 \\
14 & Komín & 3 & 2 & 3 & 2 & 10 & 29 & Židenice & 4 & 4 & 4 & 3 & 15 \\
15 & Královo Pole & 3 & 3 & 3 & 3 & 12 & & & & & & \\
\hline
\end{tabular}

Key: A - housing level, B - functional clashes, C - state of social environment, D - green areas

tral activities. On the other hand, when compared to blocks of flats estates, it is a more natural way of settlement, where this deficiency is compensated by other functional advantages.

As far as green areas are concerned, the situation of Brno is not bad, mainly in the northern half. Certain problems are to be found in central and nearcentre quarters, where green areas in the interior of blocs and in parks have been partly displaced by parking facilities and other equipment and in the southern part open to the agricultural landscape with prevailing arable land.

The total image of the residential environment differentiation in Brno in a relatively complex conception and according to individual town wards is the following: The best residential environment is in the town wards of the western half of the town, in many cases in spatially separated annexed settlements. Among the inner parts of Brno, the best residential environment is in Jundrov and Zabovřesky, on the other side in Rečkovice and Medlánky. They are town quarters mainly in an articulated relief directly linking with large forest areas in the neighbourhood of the town and with a high ratio of family houses in the housing structure. Similar characteristics are to be found in some new blocks of flats estates, as for instance in Kohoutovice and Komín, while the majority of the other ones reach only average values.

An average residential environment can be found in the majority of inner parts of Brno, a typical one being Královo Pole. Until 1919, this town quater had been an independent town. Since that time, it has maintained many elements of the structure of an independent town with all the types of housing and functional clashes. With the criteria used, it must necessarily represent a mean value.

\section{Detail: Brno - Centre}

On the territory of the town ward Brno - Centre, there are all functional zones of a town, that is the centre, the subcentral zone, the industrial zone including the energetic centre, the transport-storage zone, the residential 
zone, the recreation zone and even agricultural areas. Differently from the majority of other town wards, it can be considered as a full-value town.

The relief of this town ward is diverse. Its central and north-western part is formed by articulated grounds of isolated hills, the most important of which being Špilberk, Žlutý kopec, Kraví hora and Červený kopec on the right Svratka River bank. The southern and partly also the western part in the meadows of the Svratka and the Svitava Rivers have a plain relief. The contact zone between the articulated relief of the northern part and the flat relief in the south probably were, together with the Svratka River ford, the initial localization factor of the town constitution. The Svitava river, forming the western border of the town ward, was the initial localization factor of the industry.

The centre of Brno is limited by the historic city, once situated inside the walls. A great part of the centre is pedestrian zone. The southern part is closed by the railway station. From the point of view of individual transports, parking becomes a serious problem.

The housing resources of the near-centre zone are partly very precious. They are mainly older flat houses in classical street form. A great part of residential buildings and complexes have a great urban and often also architectural value and have rather large and well organized flats. Their technical state, given by the age of the housing resources, represents often a problem. Valuable is the proximity of the centre, as well as sufficient green areas in parks and within the blocks of houses. The intensive transit transports are a disadvantage.

Eastwards and south-eastwards from the centre, the subcentral activities are in a bizarre way mixed with production areas. In these parts, the subcentral zone has become a refuge of the socially deprived population. This fact deteriorates the level of social environment and sensibly reduces the attractiveness of the near-centre zone.

The project "Southern Centre Brno" is being realized at the southern margin of the centre. There will be mainly super-urban tertiary and quaternary activities profiting of the very advantageous position as far as of the connection to the external transport systems, completed by housing and green areas. This part of Brno could play in future a decisive part in connection of Brno to the external world.

The industrial zone is situated at the eastern and southern margins of the town ward Brno-Centre. The older eastern part is limited by water courses, the younger southern one by the transport zone next to the railway station and today also by a highway junction. Sporadically, there are also isolated older industrial works, for instance in Staré Brno, on the territory of the town ward Brno-Centre.

Among the both industrial districts, the eastern one including the energetic centre of the town and the oldest factories of textile and machinery industries, is more problematic. The problems are due not only to exhalations, but also to the state of buildings and mainly to the mixture of industrial and other activities, housing included. In addition, this industrial zone is situated in the immediate proximity of the centre and limits the eastward development of the near-centre zone. The localization of the southern industrial zone, including research institutes and other modern infrastructure, is more advantageous. The zone crosses the borders of the town ward Brno-Centre and continues southwards.

One of the most serious functional clashes is the transport situation in the town ward Brno-Centre, where local transports intersect the urban and the 


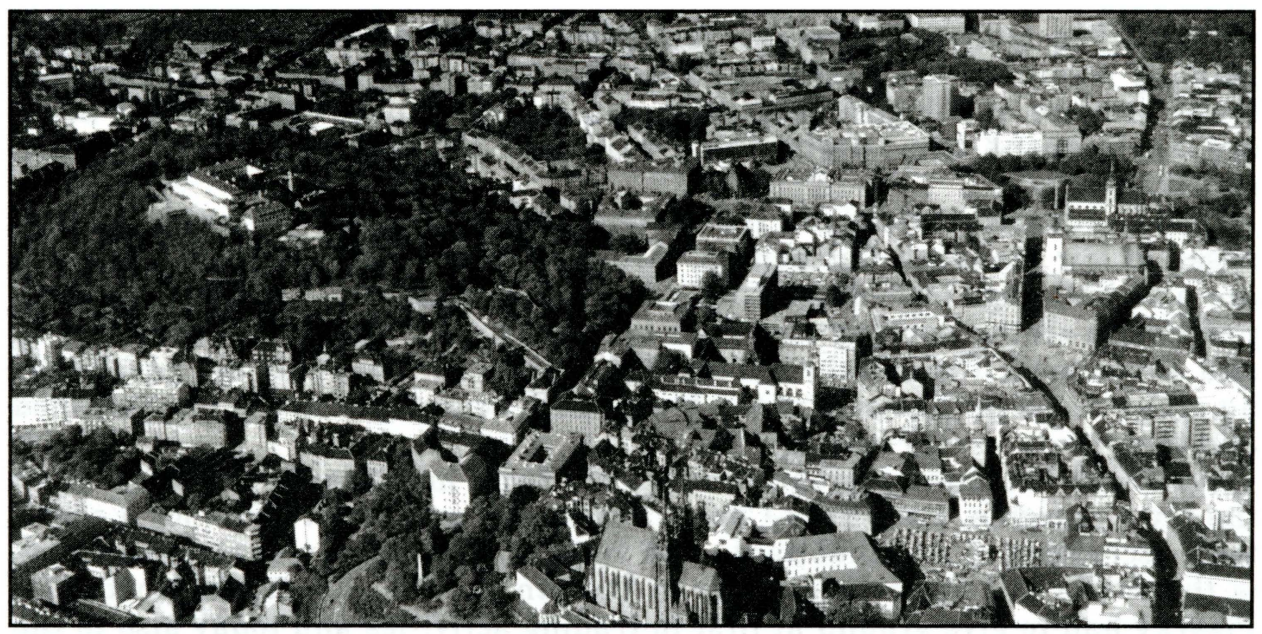

Fig. 2 - Panoramic view of Brno-central part (postcard)

inter-urban ones. The basic problem of the public transport system is its crossing and its connection to the external transport system. Electric transport traction does not pollute the environment, but it affects the environment by noise.

The problem of the Brno railway station has been discussed since a long time. Its location at the eastern margin of the centre was optimal in the past and even today it is very advantageous for the inhabitants and the visitors of Brno. Its transfer to the south is motivated by efforts to enlarge the centre in this direction and by capacity reasons. The Brno bus station at Zvonarka is probably one of the largest in Central Europe. Its accessibility from the northern parts of Brno, where building of new houses estates was recently concentrated, is however problematic. Parking is a great transport problem in the centre. Brno nearly lacks great capacity lay-by garages and parking places at the centre margin.

The inner transport circular road uses areas situated at the place of the ancient town walls demolished at the beginning of the 19th century. At present, this system is beginning to be congested in consequence of a rapid development of individual transports. As the external circular roads by-passing the inner town are not yet finished, this serious functional clash is even aggravated by transit transports.

An important residential zone with a high part of family houses has developed in the articulated relief of Žlutý kopec and Kraví hora. Initially, they were quarters of high middle classes of the Brno population. This housing is characterized by a stable social environment (given also by the ownership situation), by a higher individuality of residential environment, by a higher standard of technical and social equipment and of surface per habitant and by a relative abundance of green areas. The distance from the centre is not great, connection through trolleybus transports is optimal. The location of the district is prestigious.

Housing capacities mixed with infrastructure and other activities are characteristic for Štýrice southwards from the centre. Less marked residential districts are also in other parts of the town ward Brno-Centre. They are old flat houses from the period between two wars, from the fifties and from later 
periods. The transport position of Štýryce is also advantageous. However, housing resources are partly obsolete. The quality of social environment is lower because of a higher migration and ageing of population. Green areas are less frequent. Some parts of this residential zone are affected by an intensive traffic.

The residential districts in the eastern margin of the town ward are composed of low standard flat houses, initially intended for workers. But there are also buildings intended initially for middle classes. At present however, practically all the housing resources are devastated, locally quite devastated and abandoned. The social environment is problematic. There are practically no green areas in that part of the town and if some, they are not maintained and their state is very bad.

Although the main recreation areas for Brno inhabitants are situated at the town margins, even Brno-Centre disposes of number of areas for a shortterm recreation of its inhabitants and visitors. An important recreation zone is the castle hill Spilberk directly in the centre. The recreation function of Pisárky had to give ground at first to trading activities and today also to the circular road. Important recreation areas are also the Lužánky park, the Kraví hora zone with observatory, swimming pool and health area and number of smaller parks and public green areas.

A specific green area is the central cemetery at the southern margin of the town ward. At present however, town parks have become less safe, mainly at night hours.

A specific Brno zone is the exhibition grounds, built in 1928 in an attractive zone of the Pisárky valley. Some of its constructions are architectonic

Table 2 - Evaluation of the residential environment in the town ward Brno-Centre

\begin{tabular}{|c|c|c|c|c|c|c|c|c|c|c|c|c|c|}
\hline & part & $\bar{A}$ & B & C & D & total & & part & A & B & $\mathrm{C}$ & D & total \\
\hline 1 & hrad Špilberk & 3 & 1 & 3 & 1 & 8 & 34 & nám. Míru & 2 & 1 & 1 & 2 & 6 \\
\hline 2 & nám Svobody & 3 & 2 & 3 & 3 & 11 & 35 & Rezkova & 1 & 1 & 2 & 2 & 6 \\
\hline 3 & Zelný trh & 3 & 4 & 4 & 3 & 14 & 36 & Gorkého & 3 & 2 & 3 & 3 & 11 \\
\hline 4 & Janáčkovo divadlo & 3 & 2 & 3 & 2 & 10 & 37 & Konečného nám. & 2 & 2 & 3 & 3 & 14 \\
\hline 5 & Pekařská & 4 & 3 & 4 & 4 & 15 & 39 & Mášova & 4 & 2 & 4 & 4 & 14 \\
\hline 7 & Václavská & 3 & 3 & 4 & 4 & 14 & 40 & $\mathrm{U}$ stadionu & 3 & 2 & 3 & 4 & 12 \\
\hline 8 & Nové sady & 3 & 4 & 3 & 4 & 14 & 41 & Dřevařská & 3 & 2 & 3 & 3 & 11 \\
\hline 9 & Úvoz & 3 & 3 & 3 & 3 & 12 & 68 & tř. kpt. Jaroše & 3 & 2 & 3 & 3 & 11 \\
\hline 10 & Žlutý kopec & 2 & 2 & 3 & 2 & 9 & 70 & Přiční & 4 & 4 & 5 & 5 & 18 \\
\hline 11 & Rybářská & 2 & 3 & 4 & 3 & 12 & 71 & Soudní & 5 & 4 & 5 & 5 & 19 \\
\hline 12 & Kamenná & 4 & 1 & 3 & 2 & 10 & 72 & Hvězdová & 5 & 4 & 5 & 4 & 18 \\
\hline 13 & Bakalovo nábř. & 3 & 2 & 4 & 4 & 13 & 73 & Tkalcovská & 4 & 5 & 5 & 5 & 19 \\
\hline 14 & Stráñ & 2 & 3 & 4 & 3 & 12 & 74 & Vranovská & 4 & 3 & 5 & 4 & 16 \\
\hline 15 & Havlenova & 3 & 2 & 4 & 2 & 11 & 92 & Špitálka & 4 & 5 & 5 & 5 & 19 \\
\hline 16 & Vsetínská & 2 & 3 & 3 & 3 & 11 & 96 & Skořepka & 4 & 5 & 5 & 4 & 18 \\
\hline 20 & Vinařská & 2 & 2 & 2 & 2 & 8 & 97 & Stavební & 5 & 5 & 5 & 5 & 20 \\
\hline 22 & Neumannova & 2 & 1 & 2 & 2 & 7 & 98 & Masná & 4 & 4 & 5 & 4 & 17 \\
\hline 23 & Kamenomlýnská & 1 & 1 & 1 & 2 & 5 & 100 & Uhelná-Opuštěná & 3 & 5 & 5 & 4 & 17 \\
\hline 27 & Červený kopec & 1 & 1 & 1 & 1 & 4 & 102 & Rosická & 5 & 4 & 3 & 4 & 16 \\
\hline 33 & Vaňkovo nám. & 2 & 1 & 2 & 2 & 7 & & & & & & & \\
\hline
\end{tabular}

Key: A - housing level, B - functional clashes, C - state of social environment, D - green areas 
dominants of Brno. Among the main problems of the exhibition grounds, let us mention the transport connection and an insufficient social infrastructure in the immediate neighbourhood. Parking places are insufficient for the present traffic density. Depart of visitors after the end of working hours regularly causes a transport collapse.

The inter-urban structure of Brno-Centre has developed historically. In its time, location of each activity had its logic. The last fifty years have affected the Brno-Centre structure less than the other town wards. The present problems of the inter-urban structure are logically those of the inner parts of historic cities in interaction with physical ageing of objects. The years of socialism were characterized rather by non solving of existing problems.

The main territorially functional clash of the urban ward Brno-Centre is the conflict between transports and the other functions and equally the conflict between different transports types and routes. Although this problem is apparent mainly in the urban ward Brno-Centre, it is the result of the transport system of the whole town. A serious conflict problem is that of the eastern industrial zone and mainly of terrains between the railway and the bus station. Another conflict represents the building and structure state of certain parts of the near-centre zone.

An evaluation of the residential environment has been done only for the districts with residential function. The non-residential districts have been taken in consideration when analysing the neighbourhood effect. Evaluation of individual districts is given in Figure 3 and Table 2.

On the territory of the town ward there are not only all the functional zones typical for a town of Brno size and function, but nearly the whole spectrum of problems of residential environment (with exception of spatially separated block of flats estates and former villages attached to Brno relatively recently). Extreme levels of the residential environment quality are at one hand in the districts of family houses in Stránice and Pisárky with a stable social environment, sufficient green areas and a low intensity of functional clashes, and on the other hand in the districts with damaged housing resources in Zábrdovice and Trnitá with a high occurrence of socially problematic groups of population, lacking green areas and serious clashes between their housing, productive and transport activities.

The average level of residential environment is to be found mainly in residential districts in the central and in a great part of subcentral zones, mainly in the northern and western corridor. The indices of housing level reach average values, green areas are sufficient, functional conflicts are due mainly to clashes with intensive transports and to a great quantity of different activities. Even here there are socially problematic groups of inhabitants either living there or bound to the railway station or other activities.

\section{Conclusion}

The paper has been initially intended as an information for the Brno town council. Its aim was not to evaluate the regional differentiation of the residential environment quality for the needs of the decision making process in view to improve it, but to include other problems, namely air pollution monitoring, into the global environment situation in the town from the viewpoint of the inhabitant. We do not suppose that its importance should consist in 


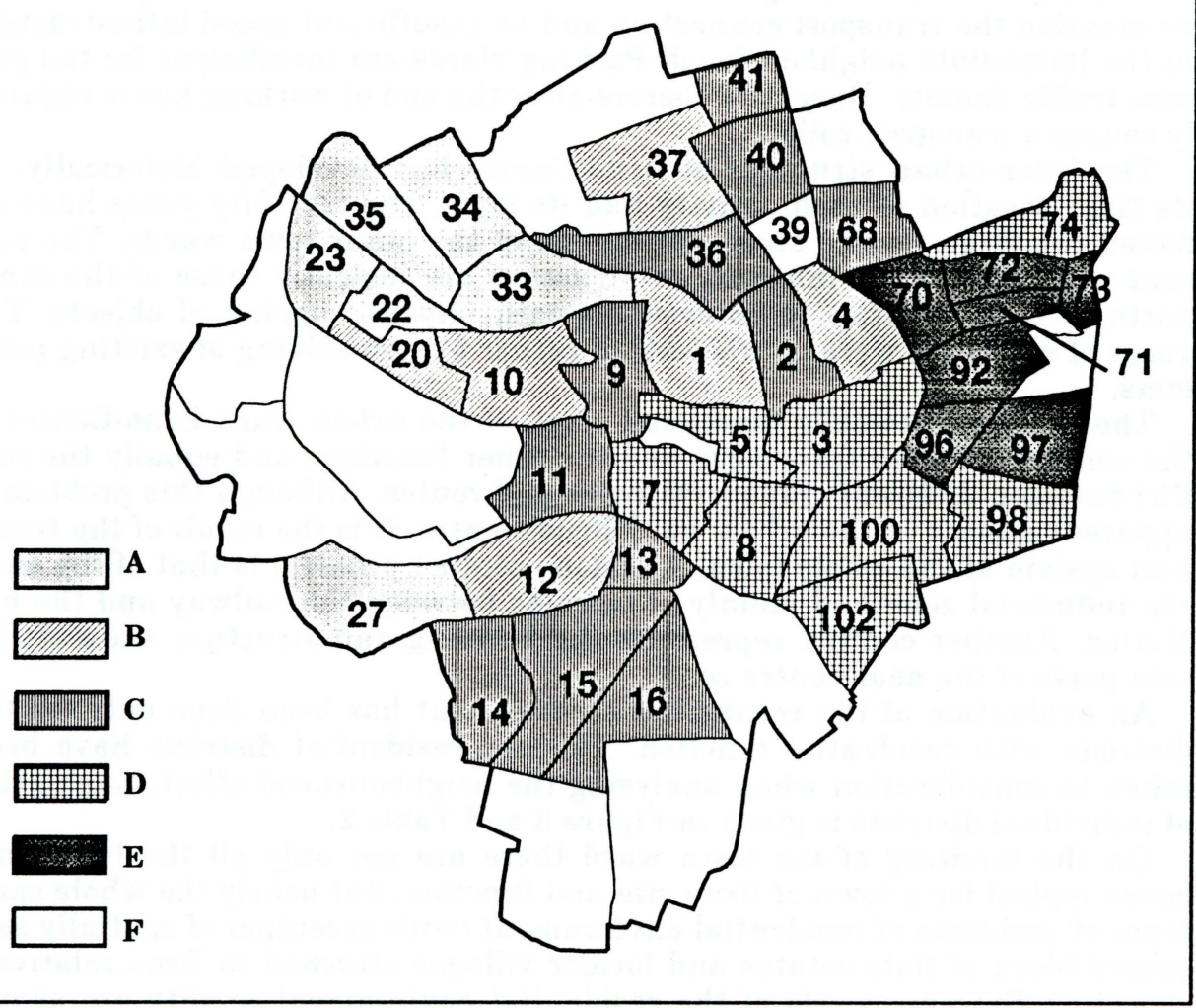

Fig. 3 - Brno-center: Quality of dwelling environment: A - very good (4-7 points - see Table 1), B - good (8-10), C - medial (11-13), D - poor (14-17), E - very poor (18-20), F - areas without dwelling function

concrete evaluation of the residential environment differences, which should be more or less known in the Brno decision-making sphere. On the contrary, intuitive findings about the differences of the residential environment quality in Brno have shown us that our method correspond to the reality as known empirically. It induces a certain probability of illustrating principal differences in the residential environment quality even in an other, not quite known town.

The aim of this paper has been to present the philosophy of one approach to the analysis of the residential environment in towns. We wanted to introduce the residential environment as a relatively complex category formed by natural, technical and social factors. It is also an attempt to present an alternative to the ecological evaluation of environment stressing mainly biological aspects.

In any case we did not want to calculate the quality of the residential environment on the basis of fixed algorhitms or to elaborate generally usable methods of its evaluation. On the contrary, we would like to stress traditional geographical methods as observation, field mapping, interviews, etc. The experience in perceiving the life of a town and of its individual parts can sometimes better reflect the reality than exact methods. 
HAPL, L., LINK, J. (1985): Ekologická úroveň vnějšího obytného prostředí projektů experimentálních obytných souborů a její hodnocení. Výstavba a architektura, 31, No. 6, pp. 3-15.

HORKÝ, I. (1984): Tvorba obytného prostředí. SNTL, Praha, p. 339.

OČOVSKÝ, Š. (1989): Domy, byty, bývanie. Veda, Bratislava. 238 p.

SÝKORA, L. (1993): Gentrifikace: měnící se tvář vnitřních měst. In: Sýkora, L. (ed.): Teoretické př́stupy a vybrané problémy v současné geografii. Univerzita Karlova Praha, pp. 100-119.

VAISHAR, A. (1988): Geografický výzkum sociálního prostředí. In: Využití moderních metod pro geografický výzkum životního prostředí. Geografický ústav ČSAV Brno, pp. 107-113.

VAISHAR, A. (1989): Výzkum obytného prostředí jako parciálně syntetický přístup k životnímu prostředí urbanizovaných geosystémů. Zprávy GGÚ ČSAV, 26, No. 3, pp. 5-13.

VAISHAR, A. (1990): Diferenciace obytného prostředí malého města ČSR. In: Problémy venkovského osídlení, malých a středně velkých měst a jejich demografické struktury. VÚVA/ČSDS, pp. 212-215.

VAISHAR, A. (1995): Transformace společnosti a změny územně funkční struktury měst. In: Miscellanea geographica 4, Západočeská univerzita Plzeň, pp. 95-102.

VAISHAR, A., MIKULÍ, O., ZAPLETALOVÁ, J. (1995): The Town of Brno: Functions, Prospects, Environment. In: Vaishar, A. (ed.): Geography and Urban Environment. Regiograph Brno, pp. 102-112.

VAISHAR, A., MIKULIK, O., ZAPLETALOVÁ, J., BARTÁK, R., DOKOUPIL, M. (1995): The Cultural and Economic Conditions of Decision-Making for the Sustainable City: Case Study Brno. Moravian Geographical Reports, 3, No. 1-2, Institute of Geonics Brno, pp. 4-29.

ZAHRADNÍČEK, L. (1993): Brno - město uprostřed Evropy. In: Mezinárodní konference Brno - město uprostřed Evropy. Magistrát města Brna, Brno, pp. 12-14.

\section{Shrnutí}

\section{OBYTNÉ PROSTŘEDÍ A ÚZEMNĚ FUNKČNÍ STRUKTURA MĚSTA BRNA V OBDOBÍ TRANSFORMACE}

Jedním z aspektů chápání životního prostředí ve městě je koncepce obytného prostředí. Obytné prostředí je definováno jako ta část životního prostředí člověka, v níž se realizuje převážně komplexní funkce bydlení. Bydlení je proces cyklicky se opakujících a proměňujících činností obyvatel, zaměřených na reprodukci a rozvoj jejich života. Obytné prostředí se dělí na vnitřní (byt a dủm) a vnější. Skládá se $z$ aspektủ přírodních, technických a sociálních.

Hodnocení kvality obytného prostředí bylo provedeno ve městě Brně v období, které je charakteristické transformačními změnami. Území města Brna bylo hodnoceno podle městských částí, přičemž městská část Brno-střed byla analyzována podle urbanistických obvodů. $\mathrm{V}$ úvahu byly vzaty aspekty kvality a obložnosti bytového fondu, funkční střety nepříznivé z hlediska obytného prostředí ( $z$ nich nejčastější je narušení prostředí tranzitní dopravou), kvalita sociálního prostředí ( $t j$. prostředí tvořeného samotnými obyvateli sledovaných obytných částí) a kompenzace nepříznivých environmentálních jevủ prostřednictvím zelených ploch. Každý $\mathrm{z}$ uvedených aspektů byl hodnocen bodovou škálou v rozmezí $1-5$.

Nejhưře byly hodnoceny městské části Brno-střed a Brno-jih, kde dochází $\mathrm{k}$ nejintenzivnějším střetům funkcí. $\mathrm{V}$ případě centra Brna je však nutno brát $\mathrm{v}$ úvahu vysokou atraktivitu plochy a historického prostředí. Další skupina městských částí $\mathbf{s}$ funkčními problémy se nachází $v$ jihovýchodním sektoru. Průměrně jsou hodnocena jednak funkčně jednostranně rozvinutá sídliště, jednak řada větších městských částí s rozmanitými funkcemi. V posledním případě je ovšem průměrné hodnocení výsledkem zprủměrování rozdílných hodnot. Hlavním funkčním problémem bývalých venkovských sídel na okrajích Brna je jejich odlehlost od centrálních aktivit. Na druhé straně ve srovnání se sídlišti jde o přirozemější způsob osídlení.

Celkový obraz diferenciace obytného prostředí ve městě Brně v relativně komplexním pojetí a podle jednotlivých městských částí je následující: Nejkvalitnější obytné prostředí je 
$\mathbf{v}$ městských cástech západní poloviny města, a to $\mathbf{v}$ mnoha prrípadech $\mathbf{v}$ prostorově oddělených připojených sídlech. Z vnitřních částí Brna je nejkvalitnějǔí obytné prostředí v Jundrově a Žabovřeskách a na druhé straně v Rečkovicích a Mendlánkách. Jde o městské části zpravidla $v$ členitějším reliéfu, bezprostřednè navazující na rozsáhlé lesní plochy v okolí města a s vysokým podílem rodinných domů ve struktuře zástavby. Podobné charakteristiky mají i některá nová "sídlištěn, z nichž nejkvalitnější obytné prostředí je v Kohoutovicích a Komínè, zatímco většina ostatních spadá do prủměru.

$\mathrm{Na}$ území městské části Brno-střed se vyskytují nejen všechny funkční zóny, typické pro města velikosti a funkce Brna, ale i téměr celé spektrum problémů obytného prostředí. Extrémními hodnotami kvality obytného prostředí jsou na jedné straně okrsky rodinných domủ katastrálních území Stránice a Pisárky se stabilním sociálním prostředím, s dostatkem zeleně, nízkou intenzitou funkčních střetů a na straně druhé okrsky zchátralého domovního fondu $\mathrm{v}$ katastrálních územích Zábrdovice a Trnitá $\mathrm{s}$ nadprůmèrným výskytem sociálně problémových skupin obyvatelstva, s nedostatkem veřejné zeleně a závažnými střety mezi bydlením, výrobními a dopravními aktivitami.

Prủměrnou kvalitu obytného prostředí reprezentují zejména obytné okrsky centra a značné části subcentrální zóny zejména v severním a západním koridoru. Ukazatele úrovně bydlení zde dosahují prủměrných hodnot, veřejné zeleně je dostatek, funkční konflikty vyplývají zejména ze střetů $s$ intenzivní dopravou a $z$ nahromadění rủzných aktivit. I zde se vyskytují sociálně problémové skupiny obyvatel.

Smyslem tohoto příspěvku bylo představit filozofii jednoho $z$ př́stupů $k$ analýze životního prostředí ve městech. Šlo o to uvést obytné prostředí jako relativně komplexní kategorii tvořenou př́rodními, technickými i sociálními faktory mimo jiné i jako pokus postavení alternativy $\mathrm{k}$ ekologickému hodnocení životního prostředí, kladoucího do centra pozornosti biologické aspekty. V žádném př́ípadě nám nešlo o "vypočtení" kvality obytného prostředí na základě stanovených algoritmů. Chceme naopak zdủraznit tradiční geografické metody jako pozorování, mapování v terénu, rozhovor a podobně. Zkušenost při vnímání života města a jeho jednotlivých částí může někdy odrážet podstatu reality lépe než exaktní metody.

Obr. 1 - Brno: kvalita obytného prostředí: 1 - velmi dobrá (7-8 bodů - viz tab. 1), 2 - dobrá (9-10), 3 - prủměrná (11-12), 4 - špatná (13-14), 5 - velmi špatná (15-16)

Obr. 2 - Panorama městské části Brno-střed (pohlednice)

Obr. 3 - Brno-střed: kvalita obytného prostředí: 1 - velmi dobrá (4-7 bodủ - viz tab. 1), 2 dobrá (8-10), 3 - prủmèrná (11-13), 4 - špatná (14-17), 5 - velmi špatná (18-20), 6 území bez obytné funkce

(Authors are with Institute for Geonics, Drobného 28, PO box 23, 61300 Brno)

Arrived to the editor's office on February 6, 1996 Recommended for publication by Radim Perlin 